\title{
Programové východiská transformácie predmníchovskej štátnosti v ludovodemokratický režim
}

Peter Mosný *

DOI: https://doi.org/10.24040/sap.2020.7.4.279-299

\begin{abstract}
Abstrakt:
MOSNÝ, Peter: Programové východiská transformácie predmníchovskej štátnosti v l'udovodemokratický režim. Článok predstavuje základné predstavy domáceho a zahraničného slovenského odboja počas II. svetovej vojny o podobe režimu povojnovej Československej republiky. Okrem názoru na dôslednú štátoprávnu obnovu predmíchovského Československa existovala aj predstava o modifikácii režimu predmíchovskej ČSR cestou jeho transformácie, ktoré pod vplyvom posilovania významu Sovietskeho Zväzu vo vojne nadobudla podobu l'udovodemokratického zriadenia.
\end{abstract}

\section{Kl’účové slová:}

II. svetová vojna, sociálne zákonodarstvo, Československo, l’udovodemokratický režim

\section{Programmatic Starting Points for the Transformation of pre-Munich Statehood into a People's Democratic Regime}

\begin{abstract}
:
MOSNÝ, Peter: Programmatic starting points for the transformation of preMunich statehood into a people's democratic regime. The article presents the basic ideas of domestic and foreign Slovak resistance during The Second World War on the form of the regime of the post-war Czechoslovak Republic. In addition to the opinion on the consistent state restoration of Czechoslovakia (1918-1938), there was also the idea of modifying the regime of Czechoslovakia (1918-1938) through its transformation, which under the influence of strengthening the importance of the Soviet Union in the war took the form of a people's democratic establishment.
\end{abstract}

Key words:

World War II, social legislation, Czechoslovakia, People's Democratic Regime

Vypuknutie a priebeh II. sv. vojny zásadným spôsobom modifikovali politické postoje širokého českého i slovenského politického spektra tak v relácii zahraničného i domáceho hnutia odporu. Rozhodujúcou otázkou boli predstavy o povojnovom štátoprávnom usporiadaní na československom území spolu s podobou vnútorného

Prof. JUDr. Dr. h. c. Peter Mosný, CSc. Profesor emeritus, Harčárova 13, 040 18, Košice, Krásna, Slovensko. 
režimu. Teda, či dôjde k presadeniu koncepcie dôslednej obnovy predmníchovskej československej štátnosti. Druhou možnostou sa javila jej do značnej miery pozmenená podoba dotýkajúca sa predovšetkým sféry hospodárskej, ekonomickej a sociálnej. Nemenej dôležitou bolo riešenie problémov národno - štátnych.

Všetky tieto okolnosti zamestnávali postupne konštituujúce sa odbojové centrály tak mimo českého a slovenského územia ako aj v jeho rámci. Konštantné východiskové pozície udávali zahraničné odbojové centrá. Prvé v Londýne, reprezentované benešovskou štátoprávnou reprezentáciou v podobe Dočasného štátneho zriadenia československého. Táto sa usilovala o dôsledné zachovanie predmníchovských pomerov v povojnovom období. Druhé centrum v Moskve predstavovala politická gottwaldovská reprezentácia Komunistickej strany Československa / d’alej len KSČ / v podobe Zahraničného byra KSČ hlásajúcou komunistické predstavy o zásadných zmenách na našom povojnovom území ako výsledku socialistickej revolúcie.

Rozhodujúcou aktivizačnou silou pre modifikáciu v podstate nezmieritel'ných predstáv oboch uvádzaných odbojových centier v zahraničí sa stal domáci odboj. Ani nie tak v Protektoráte Čechy a Morava. Nezastupitel'né miesto v tomto smere zohral odboj na území Slovenska zapadajúci do rámca existencie prvej Slovenskej republiky.

Odbojové zoskupenia na západ od rieky Moravy patrili tak do občianskeho ako aj do komunistického odboja. Nekomunistické hnutie odporu predstavovalo značne širokú škálu názorov a stanovísk na zásadné otázky budúceho povojnového štátneho usporiadania. Na spoločnej jednotiacej platforme dominovala obnova národnej slobody a štátnej suverenity. Prejavujúci sa radikálny nacionalizmus vyústoval do požiadaviek transferu všetkých Nemcov z územia povojnového Československa ako formy odvety, za krivdy spáchané na českom národe okupáciou.

Na rozdiel od občianskeho odboja, kde z prioritného národného záujmu sa odvíjali sociálnoreformné a d’alšie otázky, vedúcou ideou v roku 1939 formujúceho sa komunistického odboja bola orientácia na sociálnu revolúciu. ${ }^{1}$ Po vypuknutí druhej svetovej vojny, na základe pokynov Zahraničného byra KSČ v Moskve, dochádza ku zmene orientácie komunistického odboja na západ od rieky Moravy v upriamení na socialistickú revolúciu. Východiskových stanoviskom sa stalo dogmatické hodnotenie obojstranne imperialistického charakteru vojny. Preto komunistický odboj od jesene 1939 zaujal krajne nepriatel'ské stanovisko voči osobe E. Beneša a jeho domácim stúpencom označujúc ich za agentov západného imperializmu.

Prepadnutie Sovietskeho zväzu nacistickým Nemeckom v júni 1941 prispelo k zásadným zmenám v celkovej situácii českého domáceho odboja. Komunistický odboj začal zdôrazňovat' prioritu národnooslobodzovacieho zápasu vedeného na platforme širokého protifašistického frontu. $V$ predchádzajúcej etape favorizované revolučné ciele boli modifikované a zoslabené, aj ked' komunistický odboj sa ich nikdy nevzdal. $Z$ čisto taktických dôvodov dochádza, na základe pokynov benešovského londýnskeho odboja, k zaujatiu prijatel’nejšieho postoja domáceho občianskeho nekomunistického odboja k možnému zjednoteniu s odbojom komunistickým. ${ }^{2}$

1 Až do jesene 1939 táto nebola priamo spájaná s proletárskou revolúciou, vychádzala $\mathrm{z}$ ducha protifašistického programu VII. Kongresu Komunistickej internacionály.

2 Stroskotal však pokus o vytvorenie spoločného orgánu občianskeho a komunistického odboja pod názvom Ústredný národne revolučný výbor. 
Ostáva tak faktom i historickou pravdou, že napriek nemalému úsiliu a nemnohým l’udským obetiam domáce české občianske i komunistické hnutie odporu nedokázali ani v predposlednom roku vojny, v roku 1944, zorganizovat' širšie masové vystúpenie obyvatel'stva proti nemeckej okupácii a jej domácim prisluhovačom.

Neporovnatel’ne odlišná bola situácia na Slovensku po vzniku samostatnej slovenskej štátnosti 14. marca 1939. Charakter i intenzita hnutia odporu na Slovensku vychádzali z okolností vzniku slovenskej štátnosti, z medzinárodného postavenia prvej Slovenskej republiky i z rozdielneho postavenia slovenského a českého národa. Pokial' v českom odboji jeden z významných motivačných prvkov tvoril protinemecký nacionalizmus, v odboji na Slovensku sa s týmto prvkom nestretávame. Kým český národ prijal nemeckú okupáciu ako národnú tragédiu, vznik v histórii prvej samostatnej slovenskej štátnosti bol v masách slovenského národa prijímaný pozitívne. Naviac, po všetkých stránkach neporovnatel’ne priaznivejšiu situáciu vytvárala existencia prvej Slovenskej republiky pre vlastný slovenský národ, ako Protektorát Čechy a Morava pre národ český. ${ }^{3}$

Prameňom nespokojnosti na Slovensku sa v začiatkoch stali predovšetkým rozpory v politických kruhoch. Čast' významných slovenských politikov centristických strán bola po 14. marci 1949 vyradená z politického života v neprestávajúcej vzájomnej historickej náboženskej kontraindignácii „evanjelici verzus katolíci“. Tento krát, v porovnaní s predmníchovským obdobím, v prospech politikov katolíckeho vierovyznania. Nedotknuté hospodárske pozície a sila od vládnej moci odstavených politikov však vykazovali značný stupeň nezávislosti od vládnuceho režimu. Stali sa tak ekonomickým základom občianskeho, nekomunistického hnutia odporu. Silné jednoznačne protikomunistické zameranie oficiálnej slovenskej autonomistickej politiky, d’alej prehlbované po vzniku samostatného slovenského štátu, vyvolalo formovanie sa tiež komunistického hnutia odporu voči prvej Slovenskej republike.

V rovine občianskeho hnutia odporu až do letných mesiacoch roku 1939 nemožno hovorit' o jeho organizovanosti. Postupne však došlo $\mathrm{k}$ vykryštalizovaniu dvoch programových línií v závislosti od predstáv riešenia budúceho vnútorného štátoprávneho usporiadania na Slovensku. Spoločným menovatel’om bolo odstránenie domáceho autoritárskeho režimu. Líšili sa v názoroch na povahu štátoprávneho začlenenia územia Slovenska. Na strane jednej bol záujem o povojnové zachovanie samostatného Slovenska, druhá línia videla budúcnost' v obnovení česko - slovenskej štátnosti bez akceptácie prežitých čechoslovakistických ideí. ${ }^{4}$

Okrem opozície zostávajúcej mimo ideovej a straníckej orientácie vládneho režimu prvej Slovenskej republiky existovala aj opozícia v radoch prominentov Hlinkovej slovenskej l'udovej strany. K jej významným predstavitel'om patril okrem M. Sokola predovšetkým K. Sidor. Skupina okolo K. Sidora politicky vychádzala z odmietania pronemeckej pronacistickej orientácie slovenského štátu spolu so zachovaním jeho

3 Na Slovensku sa nestratilo zo stále živej pamäti slovenského obyvatel'stva postavenie Slovenska a slovenského národa v predmníchovskom Československu, vychádzajúce z teórie čechoslovakizmu. Navyše aj okolnosti vzniku a trvania autonómneho zriadenia v roku 1938 - 1939.

4 Na Slovensku sa ako najaktívnejší slovenský politik začal prejavovat' J. Lichner združujúci okolo seba hlavne príslušníkov bývalej agrárnej strany nespokojných s režimom prvej Slovenskej republiky, zároveň však stojaci na platforme československej štátnosti. 
štátnej samostatnosti. ${ }^{5}$

V závere roku 1939 dochádza k prvému pokusu o vytvorenie jednotnej organizačnej platformy občianskeho hnutia odporu na Slovensku. Jablkom sváru a nezmieritel'nej odlišnosti sa stali názory na budúce povojnové štátoprávne usporiadanie Slovenska. Pokial' J. Lichner zaujal neústupčivé stanovisko obnovenia spoločnej československej štátnosti v predmníchovských intenciách zásadne tak odmietajúc slovenskú samostatnost' v akejkol'vek podobe, tak K. Sidor vychádzal z ustanovení Žilinskej dohody z októbra 1938 jednoznačne tak prezentujúc zachovanie a udržanie štátnej samostatnosti územia Slovenska. Pričom predstavy skupiny K. Sidora obsahovali vo svojom návrhu značný stupeň prípadnej štátoprávnej variability v záujme dosiahnutia dohody o spoločnom postupe. ${ }^{6}$ Napriek daným skutočnostiam nedošlo $\mathrm{k}$ dohode a rozhovory stroskotali ako aj odbojová činnost' oboch ich účastníkov. ${ }^{7}$

Sledujúc skutočnosti formovania sa d'alších skupín spadajúcich do občianskeho hnutia odporu, ich činnost' až do roku 1941 výraznejšie neprispela k modelovaniu predstáv o budúcom štátoprávnom usporiadaní. Poväčšine boli čechoslovakisticky orientovaní. ${ }^{8}$ Zostáva však faktom, že až do roku 1941 domáce slovenské občianske hnutie odporu bolo len doplnkom zahraničného odboja koncentrovaného v benešovskom londýnskom zoskupení. Napriek tomu do značnej miery aktivizujúcim medzníkom pre všetky na území Slovenska pôsobiace skupiny občianskeho odboja sa stali výsledky nemecko - slovenských rokovaní v Salzburgu v júli 1941, po ktorých dochádza zo strany slovenského vládnuceho režimu k užšiemu nadviazaniu na Nemecko. To bol dôležitý impulz pre mnohých na razantnejšie zaujatie opozičného stanoviska. V konečnom dôsledku sa to prejavilo v tvrdšom postoji l'udáckeho režimu proti hnutiu odporu doma.

Okrem občianskeho, nekomunistického, hnutia odporu začal na Slovensku po vyhlásení štátnej samostatnosti pôsobit' aj odboj komunistický. Na začiatku jeho politická platforma okrem protifašistického zamerania obsahovala protibenešovské výpady, odmietajúc tak akékol'vek uznanie československých emigračných činitel'ov pôsobiacich na Západe. ${ }^{9}$ Navyše tento dokument Komunistickej strany Slovenska /d’alej len KSS/ vyjadroval predstavu, že k prípadnému zjednoteniu hnutia odporu na Slovensku malo dôjst' na zásadách komunistického programu, dokonca pod vedením komunistov.

Tieto predstavy samozrejme nemohli byt' prijatel'né pre občiansky odboj. Navyše, dokonca v Programe KSS vydanom k 1. máju 1941 sa vytýčila línia zápasu

5 Sidorovi prívrženci uznávali tiež autoritu E. Beneša, nemohli mu však odpustit' ním zastávané stanovisko odmietania samobytnej existencie i postavenia slovenského národa v predchádzajúcom predvojnovom spoločnom štátoprávnom usporiadaní.

6 Predstavy skupiny K. Sidora mali tri varianty. Na prvom mieste požadovali udržanie štátnej samostatnosti Slovenska. V prípade nemožnosti realizácie tohto projektu sa prikláňali k trialistickému štátoprávnemu spojeniu územia Čiech, Slovenska a Pol'ska. Ich poslednou tret'ou alternatívou bola spoločná česko-slovenská štátnost' výhradne v podobne pomníchovskej republiky.

7 J. Lichner v lete 1940 odišiel do emigrácie, K. Sidor napriek antinacistickým postojom voči režimu prvej Slovenskej republiky sa stal jej štátnym reprezentantom na poste vel'vyslanca vo Vatikáne.

8 V konkrétnostiach sa ich činnost’ zameriavala na získavanie spravodajských informácií, na pomoc prenasledovaným antifašistom a podobne.

9 Stalo sa tak 14. marca 1939 vo vyhlásení slovenských komunistov v dokumente Ohlas k slovenskému národu. 
za ustanovenie Slovenskej sovietskej republiky s možnost'ou jej štátneho pripojenia k Sovietskemu zväzu. Príznačným pre danú dobu dokument kompilačne vychádzal zo stanovísk Kominterny ako vrcholnej organizácie medzinárodného komunistického hnutia riadenej Komunistickou stranou Sovietskeho zväzu, terminologicky opierajúc sa o marxisticko - leninskú ideológiu. A to nie len programovo, ale aj používaním hrubo expresívnych útočných výrazových prostriedkov typu " kapitalistický svet sa zvíja v kŕčoch ... kapitalistická štruktúra spoločnosti je neznesitelným putom...zvrhnutie kapitalistického jarma...krvavý teror... vštepovanie barbarskej rasovej a národnostnej nenávisti... besná nenávist'... " a podobne. ${ }^{10}$

V komplexnejšej rovine však predstavuje budúcu formu štátneho zriadenia v celkovo ôsmych vytýčených bodoch. V nich postupne prezentuje Slovensko z pohl'adu predstáv o jeho režime v povojnovom usporiadaní. Pričom rozhodujúce sú prvé dva $\mathrm{z}$ nich. ${ }^{11}$ Išlo teda jednoznačne o program spájaný s existenciou Sovietskeho zväzu ako dokonalého vzoru spolu s viditel'nými náznakmi pripojenosti takéhoto štátneho režimu na povojnovom Slovensku do štátneho zväzku Zväzu sovietskych socialistických republík. Nič na tom nemenil obsah zostávajúcich šiestich bodov Programu slovenských komunistov dotýkajúcich sa volebného práva, existencie prevládajúcej socialistickej hospodárskej sústavy v štáte, zaručenia osobného /teda nie súkromného - pozn. P. M./ vlastníctva, slubované sociálne výhody spolu s právom na bezplatné vzdelanie, zabezpečenie slobody svedomia i spolunažívanie s českým národom na základe l'udového hlasovania. V skutočnosti išlo o ideologizáciu prísl'ubov.

Neprekvapuje preto, že až do vypuknutia nemecko - sovietskej vojny v roku 1941 možné zbližzenie sa občianskeho a komunistického hnutia odporu boli bezpredmetné. A z pohl'adu vtedajších postojov prevažnej väčšiny slovenského obyvatel'stva aj neúčelné. Prvá Slovenská republika sa v ich očiach prezentovala v atribútoch štátnej samostatnosti, nezávislosti a národnej ekonomickej prosperity. Teda $v$ tých všetkých ohl'adoch, ktoré boli Slovákom v minulom národno - štátnom vývoji upierané. Ktoré z hl'adiska možnej sovietskej socializácie religiózne založené obyvatel'stvo Slovenska rozhodne odmietalo.

Prelomom v d'alšom vývoji hnutia odporu na Slovensku bolo vojenské prepadnutie Sovietskeho zväzu nacistickým Nemeckom v júni 1941. Jeho dôsledkom, koncom roku 1941, sa aktuálne stala otázka vytvorenia centrálneho orgánu hnutia odporu zloženého z občianskych i z komunistických predstavitel’ov. K zásadnému posuvu však nedošlo. ${ }^{12}$ Neprijatel'né a vo svojej podstate kontroverzné postoje a stanoviská

10 Pozri bližšie úvodné ustanovenia dokumentu.

11 „Slovensko bude sovietskym socialistickým štátom pracujúceho l’udu, jeho vláda bude vládou robotnikov, rolníkov a pracujúcej inteligencie ako diktatúry proletariátu, to je vláda prevažnej väčšiny l’udu nad hŕstkou kapitalistov a vel'kostatkárov, teda najširšia demokracia v duchu stalinskej ústavy“. „Politickým základom Slovenskej sovietskej socialistickej republiky budú soviety /rady/ poslancov pracujúceho l’udu zvolených na základe všeobecného, priameho, rovného a tajného volebného práva “. PLEVZA, V.: Dejiny Slovenského národného povstania 1944, Dokumenty, zv. 3. Bratislava: Pravda, 1984, s. 87.

12 Následne v marci 1942 sa síce o opakovaných snahách podarilo konštituovat trojčlenný spoločný orgán pod názvom Ústredný národnorevolučný výbor, ktorý ale vôbec nereprezentoval politické spektrum jednotlivých skupín odporu na Slovensku. Preto bola jeho existencia čisto formálna a do d’alšieho vývoja nezasiahol 
slovenských komunistov nielenže odrádzali od spolupráce občianske hnutie odporu. Ale v konečných dôsledkoch znamenali pre ich predstavitel'ov cestu povojnového politického konca.

Ku kvalitatívne významnej aktivizácii občianskeho hnutia odporu na Slovensku dochádza v roku 1943 v súvislosti s činnostou skupiny Flóra i bývalého ministra predmníchovskej Československej republiky V. Šrobára.

Skupina Flóra sa neprofilovala stranícky, okolo nej sa zoskupovali osoby hlásiace sa k predmníchovskej štátnosti predovšetkým zo sociálnodemokratickej a agrárnej strany. Svoje predstavy o povojnovom usporiadaní, vyjadrené v prijatom dokumente pod názvom Memorandum z februára 1943, vychádzali z bezvýhradnej podpory programu benešovskej štátnej reprezentácie sídliacej $\mathrm{v}$ Londýne založeného na dôslednej povojnovej obnove predmníchovských pomerov na našom území.

S tým súviselo stanovisko skupiny Flóra, vychádzajúce z nedostatočne kritického zhodnotenia národnostných pomerov u nás v rokoch 1918-1938, o jednotnom československom národe, aj ked' nie všetci členovia skupiny Flóra boli stúpencami čechoslovakizmu. Napriek tomu sa všetci členovia skupiny Flóra vyjadrili v dokumente za nedelitel'ný povojnový československý štát odmietajúc súčasne jeho zmenu, ktorá nastala po 6. októbri 1938. ${ }^{13}$

Pozitívne stanovisko E. Beneša k obsahu Memoranda podnietilo v skupine Flóra myšlienku použit' Memorandum ako základ pre zjednotenie celého hnutia odporu na Slovensku. Programové stanoviská vyjadrené v Memorande skupiny Flóra sa však nemohli stat' akýmsi prazákladom pre postupné vytváranie kompromisných súvzt’ažných siločiar vo vzt’ahu k základným programovým víziám oboch zásadných jestvujúcich hnutí odporu na Slovensku - občianskeho a komunistického. Orientácia na čechoslovakizmus a bezvýhradná podpora $\mathrm{E}$. Beneša v tomto období však predstavovali príliš jedno dimenziálnu bázu, ktorá vylučovala možnost' pripustenia kompromisu nevyhnutného pri zjednocovacom procese. Svedčia skôr o nedostatočnom pochopení slovenských pomerov a názorového spektra vyskytujúceho sa $\mathrm{v}$ jednotlivých prúdoch a skupinách odporu zvláśt'. Preto tento zamýšl'aný pokus nemohol skončit' inak ako neúspechom. Navyše aj vzhl'adom na meniace sa podmienky vo vývoji druhej svetovej vojny majúce svoj výraz v modifikovaní postojov československej zahraničnej reprezentácie z konca roku 1943.

Vývoj na Slovensku v roku 1943 nad'alej jednoznačne smeroval k vytvoreniu centrálneho orgánu hnutia odporu. Tak ako dovtedy, stále zostávalo otázkou len nájdenie spoločnej vyhovujúcej platformy. Nepomohla tomu ani aktivizácia dr. V. Šrobára na konci leta 1943, vydaním dokumentu pod názvom Memorandum piatich bývalých ministrov/Šrobár, Zat'ko, Karvaš, Botto, Houdek/. ${ }^{14}$ Programová platforma dokumen-

13 V Memorande konkrétne vyjadrené slovami: „... slovenský l’ud svoj kultúrny a hospodársky rozvoj má zaistený iba v nedelitelnej Československej republike, stvorenej 28. októbra 1918 a uzákonenej dña 6. novembra 1918 pod čislom 11. Zb. z. a n. Rozhodne a dôrazne zavrhujeme činnost’ tých slovenských činitel'ov, ktori Slovensko by sice radi videli v rámci Československej republiky, avšak na podklade nanúteného žilinského rozhodnutia zo dña 6. októbra 1938“. PREČAN, V.: Slovenské národné povstanie, Dokumenty. Bratislava: Vydavatel'stvo politickej literatúry, 1965, s. 44.

14 PLEVZA, V.: Dejiny Slovenského národného povstania 1944, Dokumenty, zv. 3. Bratislava: Pravda, 1984, s. 211-213. Dokument pozostával spolu z piatich častí /Politická situácia a rozvrstvenie národa, Naše žiadosti, Plán o zariadení poriadku na Slovensku, Špeciálne úlohy, Návrat k ústavnému režimu/. V jeho štvrtej časti Špeciálne úlohy sa v niektorých jeho bodoch nachádzajú niektoré 
tu totižto vychádzala z platformy dôsledného povojnového obnovenia predmníchovských štátoprávnych, ekonomických i národnostných pomerov. Teda príprava prevratu na spôsob konštituovania sa československého štátu v roku 1918. Navrhovaný postup vo svojich podrobnostiach nevyhovoval ani benešovskej štátnej reprezentácii v Londýne. Navyše mnohé z bodov tohto dokumentu vykazovali znaky protisovietskeho i protikomunistického zamerania. A to $\mathrm{v}$ dobe rastúceho rozhodujúceho vplyvu Sovietskeho zväzu v zoskupení štátov protihitlerovskej trojkoalície. ${ }^{15}$

Nebolo preto náhodné, skôr zákonité, že predstavy V. Šrobára boli odsúdené na neúspech. Ich najzávažnejším nedostatkom bola proklamovaná politická naivita vedúceho predstavitel'a tejto skupiny s príznačne neústupčivou a známou čechoslovakistickou servilnost'ou. Preto sa V. Šrobár, až do vypuknutia celonárodného povstania v roku 1944, dostal mimo hlavného prúdu silnejúceho odbojového pohybu.

Dovtedajšie skutočnosti však v priebehu roka 1943 nič nemenili na fakte silnejúcich snáh aj zo strany iných odbojových predstavitel'ov smerujúcich k potrebnosti vytvorenia centrálneho orgánu hnutia odporu. Nad’alej sa hl'adal kompromis medzi komunistickým do značnej miery extrémtickým stanoviskom povojnovej socialistickej sovietizácie Slovenska verzus vývojom svetového vojenského konfliktu prekonané koncepcie občianskych skupín odporu o dôslednej obnove predmníchovských pomerov so všetkými z toho vyplývajúcimi atribútmi. Na zmenu dovtedy vyostrene nezmieritel'ných stanovísk mali rozhodujúci vplyv tri zásadné, nezamenitel'né skutočnosti.

V prvom rade priaznivé podmienky nastali po konštituovaní sa nového centrálneho orgánu slovenských komunistov /V. Ústredný výbor KSS/ v závere leta 1943, ktorého programová platforma opustila dovtedy zastávané uvádzané stanoviská. V zaužívanom systéme vedenia celosvetového komunistického hnutia, prísne centrálne riadeného z Moskvy, sa aj pre slovenských komunistov stala záväznou politická smernica Komunistickej internacionály v Moskve z januára 1943, ktorá bola pod patronátom sovietskych bol'ševikov. Okrem iného sa v nej konštatovalo, že "...treba národnooslobodzovacie hnutie českého a slovenského národa orientovat na všestranné stupňovanie boja proti nemeckým okupantom s perspektívou národného povstania $v$ dohl'adnom čase, $v$ súvislosti s vývojom udalostí na frontoch... ,, Majú sa tiež ,,... zomknút' všetky tie živly a skupiny, bez ohl'adu na stranícku prislušnost' a sociálny

predstavy odklonu od čechoslovakistického uplatňovania budúceho československého štátneho života v porovnaní v predmníchovskými pomermi. V konkrétnostiach jeho bodov: „, 1 . Slovenský jazyk bude štátnym jazykom na územi Československa. 5. Zaplňovanie miest vo verejnej správe na Slovensku bude zverené príslušnému úradu na Slovensku“. Ibidem, s. 212.

15 Východiskom štátneho prevratu malo byt’ zosadenie najvyšších štátnych orgánov prvej Slovenskej republiky. Slovenskú vládu mal zosadit' slovenský snem, namiesto ktorého sa mal ustanovit' Revolučný národný výbor s úlohou vymenovat' Revolučné národné zhromaždenie so zákonodarnými právomocami. Všetky novovzniknuté orgány na Slovensku po zabezpečení riadneho chodu štátneho a občianskeho života na Slovensku sa mali následne vzdat' svojich dočasných funkcií do rúk ústavného reprezentanta československej štátnej moci, teda prezidenta E. Beneša. V odpovedi E. Beneša na spôsob prevratu uvádzaného v Memorande skupiny okolo V. Šrobára najviac odmietané stanovisko súviselo s konaním, ktoré malo pripomínat' pokračovanie slovenskej samostatnosti prostredníctvom východiskového prevratového konania v inštitúcii slovenského snemu i ustanovenie novej slovenskej vlády i nového slovenského zákonodarného orgánu. 
pôvod, ktoré sú ochotné aktívne bojovat proti okupantom... komunisti sa nesmú nechat' strhnút' k nijakým malicherným dobovým škriepkam emigrácie a musia všade ...zastupovat' a hájit' záujem celého národnooslobodzovacieho boja. Beneša podporujeme proti útokom reakčných klik... ".16

Základnou podstatou jej obsahu aj pre slovenských komunistov bolo zanechanie prioritného sledovania mocensko - politických ciel’ov v hnutí odporu. Rozhodujúcou úlohou sa mala stat' orientácia na širokú spoluprácu v boji proti nacistickému Nemecku a jeho domácim spojencom bez určovania predbežných podmienok. ${ }^{17}$

$\mathrm{Z}$ medzinárodného aspektu prebiehajúceho druhosvetového konfliktu sa druhou významnou skutočnost'ou stali výsledky konferencie štátov protihitlerovskej koalície v Teheráne na prelome novembra - decembra $1943 .{ }^{18} \mathrm{Na}$ nej sa po prvý krát riešili otázky povojnového vel'mocensko-politického vplyvu aj v stredoeurópskom priestore. Z pohl'adu výsledkov teheránskej konferencie vyznieval reálny fakt oslobodzovacej protifašistickej misie vojsk Sovietskeho zväzu v pomere k územiu prvej Slovenskej republiky, ako aj k územiu Protektorátu Čechy a Morava. Tým nepochybne vzrástol význam zahraničného gottwaldovského komunistického hnutia odporu v Moskve, ktoré z pôvodného čisto politického orgánu začalo nadobúdat' aj štátoprávny význam spolu so sinergickým efektom vo vztahu ku rokovaniam slovenských komunistov s občianskym blokom o podobe povojnového usporiadania Československa. ${ }^{19}$

$\mathrm{Z}$ celočeskoslovenského pohl'adu, tret'ou nemenej dôležitou skutočnost'ou bolo uzavretie československo - sovietskej zmluvy z polovice decembra 1943, a to na návrh trojkoalíciou štátov protihitlerovského zoskupenia štátoprávne uznaného zahraničného československého londýnskeho hnutia odporu na čele s prezidentom E. Benešom. ${ }^{20}$

16 Pozri bližšie: Smernice prezídia Exekutívy Komunistickej internacionály O politickej línii a najbližších úlohách Komunistickej strany Československa. PLEVZA, V.: Dejiny Slovenského národného povstania, 3. Zväzok. Bratislava: Pravda, 1984, s. 141-145.

17 Na tomto základe prebiehali od jesenných mesiacocv 1943 rokovania medzi vedúcimi predstavitel'mi slovenských komunistov /K. Šmidke, G. Husák, L. Novomeský/s predstavitel'mi opozičných odbojových síl zoskupených z bývalých príslušníkov slovenskej agrárnej strany /J. Ursíny, J. Lettrich, M. Josko/ neskoršie združených do tzv. občianskeho bloku. Rokovania vyústili do podpísania Vianočnej dohody v decembri 1943 signatármi zúčastnených oboch politických zoskupení.

18 Teheránska konferencia bola prvým stretnutím vedúcich predstavitel'ov tzv. Vel'kej trojky: Spojené štáty americké v zastúpení F. D. Roosevelta, Vel'ká Británia v zastúpení W. Churchilla, Zväz sovietskych socialistických republík v zastúpení J. V. Stalina. Dotýkala sa predovšetkým stratégie spojencov na európskych bojiskách najmä v súvislosti s otvorením západného frontu. Bol tiež prijatý princíp, podporovaný Stalinom a Rooseveltom, že rozhodujúce slovo na povojnový politický vývoj v krajinách oslobodených spod nemeckej okupácie bude mat' tá mocnost', ktorej vojská vstúpili do tejto oblasti. Fakticky sa tak rozhodlo o povojnovom osude štátov strednej a východnej Európy.

19 Nezvratne sa to neskôr potvrdilo tým, že sa rozhodujúce rokovania o prvom československom povojnovom vládnom programe konali v marci $1945 \mathrm{v}$ Moskve.

20 Ustanovenia československo-sovietskej Zmluvy o priatel'stve, vzájomnej pomoci a povojnovej spolupráci z 12. decembra 1943 v úvodnej svojej časti zvýrazňovali skutočnost', že je pokračovaním zmluvy z roku 1935 i zmluvy z roku 1941. Zmluva obsahovala 6 základných článkov: a) Záväzok vzájomnej vojenskej a inej pomoci a podpory vo vojne proti Nemecku a jeho 
Podpísaním zmluvy z československej strany predovšetkým nešlo o ideologické zbližovanie sa názorových stanovísk vo vzt’ahu k podobe povojnového československého režimu. Rozhodujúcim zmluvným stimulátorom bolo upravit' povojnové vzájomné vzt’ahy medzi oboma vzájomne susediacimi štátmi tak, aby sa zabránilo zasahovaniu Sovietskeho zväzu do československých vnútorných pomerov. Zo strany E. Beneša išlo nesporne o taktický variant plánov jeho politickej západoeurópsky orientovanej platformy. V konečnom dôsledku zmluva v historickom vývoji mala poskytovat' medzinárodnoprávne vhodný rámec pre realizáciu ustanovení jaltských dohôd uzavretých štátmi tvoriacich hlavnú os protihitlerovskej koalície. Spolu tiež prostriedkom preventívneho zahnania obáv a strachu pred možnou analógiou udalostí na konferencii v Mníchove z konca septembra 1938 vo vzt’ahu ku Československu.

Všetky tieto tri rozhodujúce fakty nielenže urýchlili rokovania na Slovensku, ale prispeli $\mathrm{k}$ ich záverečnému zdarnému dojednaniu v podobe konštituovania sa celoslovenského orgánu domácej rezistencie - Slovenskej národnej rady - podpísaním Vianočnej dohody signatármi oboch pôvodne protichodných ideových zložiek hnutia odporu. ${ }^{21}$ Nič na tom nezmenil ani fakt, že do vzniknutého centrálneho hnutia odporu sa v danom rozhodujúcom čase nedostali príslušníci skupiny Flóra, skupina V. Šrobára a ani nie všetci príslušníci bývalej slovenskej agrárnej strany. ${ }^{22}$

Všeobsiahlejšie kontúry ustanovení Vianočnej dohody riešili v prvom rade otázky definitívneho pádu režimu prvej Slovenskej republiky spôsobom príprav na celonárodné ozbrojené vystúpenie. $\mathrm{V}$ tejto otázke bola bezproblémová zhoda $\mathrm{v}$ širokom spektre hnutia odporu na Slovensku už od prvých prejavov domácej rezistencie. Samotný spôsob dojednania sa na zorganizovaní celonárodného ozbrojeného vystúpenia však v mnohých smeroch prejudikoval budúce širšie dimenzie než len samotný pád bratislavského režimu. Jednoznačne, bez akéhokol'vek vylúčenia, to bolo vyjadrené v záverečnom štvrtom odseku prvej časti Vianočnej dohody v originálnom znení slovami: „, SNR bude vo svojej činnosti postupovat'v dorozumení s česko-slovenskou vládou a celým zahraničným odbojom, ktorých prácu na medzinárodnom a vojenskom

spojencom, b) Záväzok nevstúpit' do rokovaní s vládou Nemecka /alebo inou nemeckou vládou, ktorá sa nevzdá vojenských zámerov/ a bez vzájomnej dohody neuzatvárat' prímerie alebo mier s Nemeckom ani s jeho spojencami, c) Záväzok vzájomnej vojenskej a inej pomoci a podpory v prípade vojny s Nemeckom alebo jeho spojencom po skončení druhej svetovej vojny, d) Dohoda na tesnej a priatel'skej spolupráci po vojne, založená na zásadách nezasahovania do vnútorných záležitostí druhého štátu. Tiež vzájomné rešpektovanie zvrchovanosti spolu s vyvíjaním čo možno najširších hospodárskych stykov a vzájomného poskytovania hospodárskej pomoci, e) Záväzok neutvárania spojenectva alebo neúčasti na koalícii namierenej voči druhej zmluvnej strane, f) Platnost' zmluvy na 20 rokov od jej podpísania s možnost'ou jej predíženia na d’alších 5 rokov, ak jedna zo zmluvných strán nevypovie zmluvu 12 mesiacov pred uplynutím lehoty. Osobitost' podpísania zmluvy z 12. 12. 1943 spočívala v tom, že obdobnú medzinárodnú bilaterálnu dohodu československá štátna reprezentácia s iným štátom tzv. Vel'kej trojky nepodpísala.

21 K prvotným rokovacím signatárom sa začiatkom roka 1944 pridali slovenskí sociálni demokrati i d'alšie odbojové skupiny.

22 Do centrálneho zjednoteného hnutia odporu sa v čase príprav i počas ozbrojeného vystúpenia proti vládnucemu režimu zapojila prevažná väčšina z nich, opustila politiku separácie v dielčích odbojových zoskupeniach. 
poli uznáva a ju podporuje. “23

Teda rozhodne nie $\mathrm{v}$ podradenom postavení $\mathrm{k}$ obom československým zahraničným centrám odboja pôsobiacim v Londýne i v Moskve. Ale len v dorozumení, vo vzájomnej zhode stanovísk vo všetkých otázkach súvisiacich aj so spôsobom pripravujúceho sa štátneho prevratu na Slovensku ako nevyhnutným východiskom pre sformovanie sa perspektív následne nastupujúcej podoby režimu v štátoprávnom usporiadaní. Táto kardinálna otázka nemohla tak byt' problémom podružným, ale nesporne nevyhnutne rozhodujúcim z pohl’adu vývoja situácie na východnom fronte signalizujúcom porážku nacistického Nemecka spolu s teheránskymi dojednaniami o povojnovom prekreslení dovtedajších politických sfér vplyvu aj v stredoeurópskom priestore $\mathrm{v}$ prospech vtedy už jasne sa črtajúceho vel'mocenského postavenia Sovietskeho zväzu.

Vytvoril sa tak zároveň aj stav v podstate rovnakej reálnej miery poradnej hodnoty a vplyvu štátoprávnych názorov benešovského londýnskeho štátoprávneho zoskupenia i štátoprávnych názorov politického orgánu gottwaldovských československých komunistov v Moskve v pomere ku formujúcemu sa programu zjednoteného hnutia odporu na Slovensku. V tom je nutné vidiet' vysokú štátnickú vyspelost' a zrelost' signatárov Vianočnej dohody. Teda do značnej miery vymedzujúce si ponechanie nezávislosti v spôsobe prípravy a realizácie štátneho prevratu ilegálnej Slovenskej národnej rady, tiež legálnej povstaleckej Slovenskej národnej rady i následne „povstaleckú samobytnost"“ podiel'at' sa na určovaní smeru povojnového vývoja Slovenska i celého československého štátu. A to Slovenskou národnou radou v akomkolvvek jej d’alšom vývojovom postavení a pôsobení. ${ }^{24}$

Z pohl'adu usporiadania budúcich vnútropolitických pomerov v oslobodenej republike sa rozhodujúce ustanovenia nachádzali v druhej časti Vianočnej dohody. Tieto ako celok vytvárali prvé východiskové, ucelené kontúry predstáv transformácie systému existujúceho v predmníchovskom Československu. Pod vplyvom nových reálií, tak zahraničnopolitického vývoja a stavu, ako aj vnútropolitických názorových posunov majúcich zásadné, nenahraditel'né vyjadrenie práve na Slovensku. Transformačný proces, pre ktorý sa $\mathrm{v}$ jeho postupne dokonštituovanom vyjadrení vžil názov ludovodemokratické zriadenie.

Základom pevnosti povojnového l’udovodemokratického zriadenia Československej republiky sa malo stat' spravodlivé, v skutočnosti reálne existujúce, vyriešenie postavenia Slovákov a Slovenska, vyjadrené v konkrétnosti uznaním samobytnej existencie slovenského národa a jeho vzájomného vzt’ahu k českému národu na princípe rovný s rovným. ${ }^{25}$

23 Citované podl'a: BENKO, J. et al.: Dokumenty slovenskej národnej identity a štátnosti, II. Bratislava: Národné literárne centrum, 1998, s. 319.

24 Autentické znenie Vianočnej dohody vo všetkých jej častiach má formuláciu s pomlčkou pri výrazoch česko - slovenský, Česko - Slovenská Republika. Pomlčka bola odstránená z publikácií povojnových a z normalizačných čias. Slovenská národná rada pracovala v ilegalite do vypuknutia Slovenského národného povstania, jeho momentom sa stala revolučným legálnym orgánom majúcim najvyššiu zákonodarnú, vládnu a výkonnú moc na celom území Slovenska.

25 „Želáme si, aby národ slovenský a národ český ako najpríbuznejšie slovanské národy utvárali d'alšie svoje osudy $v$ novej $\check{C}-S R$, spoločnom to štáte Slovákov a Čechov, a na podklade princípu rovný s rovným,., BENKO, J. et al.: Dokumenty slovenskej národnej identity $a$ štátnosti. Bratislava: Národné literárne centrum, 1998, s. 319. 
Svojou podstatou išlo o dvojjedinečné vyjadrenie v rovine politickej. Jednak ako jasne deklarujúce, rozhodné odmietnutie fikcie jednotného československého národa, ktorej sa pridržiavala londýnska štátoprávna reprezentácia. Ako aj vymedzenie sa k politike prvej Slovenskej republiky budovania jednonárodného štátu pri aplikácii, v spoločenskej i štátnej praxi, negativistického prístupu k príslušníkom národa českého.

V rovine štátoprávnej, prvé ustanovenie druhej časti Vianočnej dohody taktiež dvojjedinečne, jednoznačne deklarovalo predstavy v nej združených odbojových smerov a zložiek. ${ }^{26}$ Jednak obnovenie spoločnej československej štátnosti bez konkrétnosti formulovania povojnových štátoprávnych modelov vzájomne seba rovného vzt’ahu slovenského a českého národa. Zároveň, v kontexte s tým, odmietnutie nereflektovania najvyššej formy sebaurčovacieho práva každého, i slovenského, národa na vlastnú štátnu nezávislost' i samostatnost' so všetkými k tomu viažucimi sa atribútmi tak v zahraničnopolitickej ako aj vnútropolitickej oblasti.

Zásadné východiskové transformačné kritériá proti dôslednému zachovaniu predmníchovského režimu, stojaceho na nezmieritel'ne trhovom kapitalistickom hospodárstve, do budúceho povojnového l'udovodemokratického štátneho režimu sa nachádzali v piatom bode druhej časti Vianočnej dohody. ${ }^{27}$ Tieto aj ked' vo svojej nesporne bližšej nekonkretizovatel'nosti boli „,sine qua non“ jednoznačnosti obnovenia demokratického vnútorného usporiadania povojnového spoločného štátu. ${ }^{28}$ Pričom jeho nezanedbatel’nou, vo svojej podstate novou, črtou mal byt' pevný vnútorný politický režim. Bližšie nešpecifikovaná obsahová formulácia vo vyjadrení „,pevný vnútorný politický režim“ neznamenala negáciu d’alšej existencie straníckeho predmníchovského pluralizmu. V spojení „Je potrebné vystríhat' sa omylov a chýb minulosti“" vymedzovala historicky známu, v istom slova zmysle niekedy jeho, až bezbrehost' vplývajúcu na jeho nestabilitu.

Z komplexnosti pohladu na predstavy vnútorného povojnového režimu spoločného štátu Čechov a Slovákov nemožno vynechat' synergický efekt nielen ideovo požadovaného, ale dobovo existujúceho postavenia Sovietskeho zväzu k obnovenej povojnovej štátnosti na našom území v rovine medzinárodno-politickej. V danej relácii Vianočnej dohody dokonca v dvojnásobnom vyjadrení Sovietskeho zväzu ako donora vonkajšej stability povojnového Československa. ${ }^{29}$

26 Prejudikovala sa tak možnost' pripojenia i pripájania ostatných odbojových zložiek. Nie len do procesu príprav ozbrojeného vystúpenia, ale tak ako sa politicky vizionársky predpokladalo, do procesu samotného jeho priebehu i následnej realizácie budovania poprevratových zmien.

27 „, Myšlienku demokracie je treba preniest' a prehĺbit' i na pole hospodárske a sociálne tak, aby rozdelenie národného dôchodku medzi všetko obyvatel'stvo bolo čo najrovnomernejšie a aby život každého občana bol l'udský a dôstojný “. Ibidem, s. 320-321.

28 II. Čast' Vianočnej dohody bod 4 znel: ," Vnútorné usporiadanie budúcej Č-SR má byt' demokratické, majú sa vykorenit' všetky tendencie fašistické, rasistické, totalitné a také, ktoré budú v rozpore s týmito zásadami. V tomto duchu má byt' vnútorný politický režim pevne vedený, pritom však demokratický. Je potrebné vystríhat'sa omylov a chýb minulosti. “Ibidem, s. 320.

29 „, želámesiúzkuspoluprácu...menovitesoZSSR....Budúca Č-SRsamánapolizahraničnopolitickom a vojenskopolitickom opierat' o ZSSR. “. Pozri bližšie: Vianočná dohoda, II. Čast', bod 2 a bod 3. BENKO, J. et al.: Dokumenty slovenskej národnej identity a štátnosti. Bratislava: Národné literárne centrum, 1998, s. 320. O budúcom zameraní predstáv prezidenta E. Beneša v rovine zahraničnopolitickej orientácie po skončení II. Svetovej vojny svedčí československo-sovietska zmluva z 12. decembra 1943. 
Nedá sa mi nevyjadrit', že v týchto súvislostiach $\mathrm{v}$ danej dobe boli značne nepredstavitel'né dosahy budúceho takéhoto ukotvenia. Nazdávam sa totiž, že oba dokumenty - zmluva so ZSSR a Vianočná dohoda - vyjadrujúce uvádzaný pro futuro postoj sa chápali do značnej miery odlišne. Historická pamät' z minulosti, nezáleží na tom či viac či menej dávnej, poskytuje nevyvrátitel'né svedectvá o nenarušitel'nosti singularity - minimálne $\mathrm{v}$ základných východiskových princípoch $\mathrm{v}$ prepojitel’nosti zhody zahraničnopolitickej a vnútropolitickej - orientácie medzi vel'mocenským partnerom a chráneným štátnym subjektom.

Ustanovenia Vianočnej dohody v danej otázke rozhodne nekorešpondovali s Benešovými predstavami Československa ako mosta medzi Východom a Západom. Slovenskí komunisti mali v čase tvorenia ustanovení Vianočnej dohody postavenie reálne silnejšieho partnera $\mathrm{v}$ pomere $\mathrm{k}$ občianskemu bloku. Východiskom bol fakt informačnej prepojenosti na moskovské gottwaldovské vedenie odboja o výsledkoch rozhovorov na teheránskej konferencii štátov protifašistickej trojkoalície/Spojené štáty americké, Vel'ká Británia, Sovietsky zväz/ k prvotnému povojnovému členeniu Európy. Tiež vo vzt’ahu k situácii na východnom fronte, ktorá čoraz jasnozrivejšie preukazovala predpoklady vojenskej porážky nacistického Nemecka a oslobodzovacej misie Červenej armády vo vzt’ahu k územiu Československa. Nazdávam sa preto, že tu bol ten rozhodujúci bod prelomu v neskoršom povojnovom pretvorení československého štátu v prvej fáze $\mathrm{k}$ l’udovodemokratickému zriadeniu.

Proces príprav ozbrojeného vystúpenia na Slovensku predstavoval komplex spletitých politických, vojenských, kompetenčných a iných problémov. Nielenže proces zjednotenia hnutia odporu na platforme Vianočnej dohody neakceptovali všetky odbojové skupiny. Rovnako závažnou bola skutočnost' nevyhnutného napojenia civilných zložiek hnutia odporu na voči vládnucemu režimu opozične naladených dôstojníkov slovenskej armády. Ako sa neskôr ukázalo rozhodujúcou zložkou celonárodného vystúpenia $\mathrm{v}$ auguste 1944 sa stali práve príslušníci slovenskej armády. $\mathrm{Na}$ ich organizačné sformovanie sa do Vojenského ústredia mal nemalý vplyv E. Beneš, čo poznamenalo ich prvotnú jednostrannú závislost' na názoroch československej štátnej reprezentácie $\mathrm{v}$ Londýne. Až v rýchlych premenách predprevratového času v záujme zabránenia d'alším neželaným rozporom $\mathrm{s}$ benešovským vedením hnutia odporu i ostatnými doma existujúcimi odbojovými skupinami pôvodná Slovenská národná rada akceptovala nevyhnutnost' svojho rozšírenia. ${ }^{30}$ Stalo sa tak opätovne na princípe parity, použitom pri jej vzniku v decembri 1943. Teda uplatnením rovnakého personálneho zastúpenia v početnosti tak občianskeho ako aj komunistického bloku.

Nenahraditel'nost' tohto kompromisného ústupku sa v plnom rozsahu svojho významu preukázala na prvom legálnom zasadnutí Slovenskej národnej rady 1. septembra $1944 \mathrm{v}$ súvislosti s obsahom tam prijatej politicko - programovej platformy pod názvom Deklarácia Slovenskej národnej rady. V súvislosti s jej častou dotýkajúcou sa predstáv domáceho, slovenského hnutia odporu v podstate už kompletne politicky zastupujúceho celý slovenský národ, $v$ transformačnom procese predmníchovskej štátnosti. ${ }^{31}$

30 Jej súčast’ou sa stali predstavitelia skupiny okolo V. Šrobára. Zastúpenie mala tiež povstalecká čast' armády prvej Slovenskej republiky.

31 Dialo sa to v nadväznosti na prevratové konštituovanie sa Slovenskej národnej rady ako 
Povstalecká Slovenská národná rada sa tak v otázke budúceho vnútorného povojnového režimu odmietavo postavila proti myšlienke prostej vnútroštátnej kontinuity vyhlásením, že ústavnoprávne, sociálne, hospodárske a kultúrne otázky republiky budú usporiadané v duchu demokratických zásad pokroku a sociálnej spravodlivosti v spoločnej dohode zástupcov slovenského a českého národa. Zároveň Slovenská národná rada $v$ jej Deklarácii bližšie prezentovala predstavy tohto usporiadania vymedzením požiadavky na zabezpečenie št’astného života sociálne slabým triedam, spravodlivé rozdelenie národného dôchodku, na novú úpravu vlastníctva a držby pôdy v prospech malých rol'níkov i na mzdové posilnenie sociálneho postavenia robotníkov. ${ }^{32}$

Deklarácia Slovenskej národnej rady vyjadrila vo svojich ustanoveniach základný politický program suverénneho Slovenska a súčasne aj vznikajúceho československého štátu. Počas celej doby celonárodného ozbrojeného vystúpenia Slovenská národná rada prevzala nielen na povstaleckom území všetku moc ako revolučná reprezentantka slovenského národa. Súčasne aj ako predstavitel'ka Československej republiky na slovenskej časti jej územia, na ktorom sa tak fakticky i revolučno-právne obnovila Československá republika. Pričom platforma Slovenskej národnej rady bola autentická vymedzením sa spôsobom jej vzniku i formami jej pôsobenia ako orgánu, ktorý nielenže nenadväzuje na systém Dočasného štátneho zriadenia československého. Ale svoje právomoci neodvodzuje od jej orgánov. ${ }^{33}$ Tento stimul daného stavu mal autentický podiel na formovaní sa nového povojnového režimu, na jeho ludovodemokratický charakter. Nič na tom nemenili rozpory s predstavami československého londýnskeho vedenia odboja nielen počas Povstania.

Počas Slovenského národného povstania sa zvýšila aktivita slovenských komunistov o ovládnutie celého zjednoteného hnutia odporu na Slovensku. Silným mobilizujúcim stimulom bola zvyšujúca sa úloha Sovietskeho zväzu v prebiehajúcom proti nacistickom ozbrojenom konflikte spolu s reálnymi kontúrami oslobodzovacieho postupu Červenej armády na československom území. Jedným z krokov bol aj politický program slovenských komunistov prijatý v povstaleckej Banskej Bystrici 2. septembra 1944. Predznamenávalo to už v úvodných ustanoveniach Vyhlásenia Komunistickej strany Slovenska vo svojej podstate konštatovanie už úvodných ustanoveniach dokumentu slovami, že „Dnes sú v boji zjednotené všetky socialistické sily Slovenska,

vrcholného orgánu domáceho slovenského odboja, ktorý prijatím Deklarácie Slovenskej národnej rady prevzal na celom území Slovenska všetku zákonodarnú a výkonnú moc spolu s obranou Slovenska. Pozri bližšie ustanovenia Deklarácie SNR. RÁKOŠ, E.: Slovenské národné orgány v dokumentoch. Bratislava: Pravda, 1977, s. 17-18.

32 Transformačné predstavy Deklarácie Slovenskej národnej rady vo svojej podstate vychádzali z ustanovení Vianočnej dohody. V niektorých smeroch ich čiastočne konkretizovali.

33 Východiskovým bodom sa stala normotvorná činnost' SNR vydaním, 1. septembra 1944, nariadenia SNR č. 1/1944 Zb. n. SNR O vykonávaní zákonodarnej, vládnej a výkonnej moci na Slovensku. In: Sbierka nariadení SNR 1944 - 1945. Z hl'adiska kontinuity či diskontinuity práva rozhodujúcim bol $§ 2$ stanovujúci, že všetky zákony, nariadenia a opatrenia ostávajú v platnosti za podmienky neodporovania duchu republikánsko-demokratickému. Teda používanie všetkých právnych noriem vydaných na území Slovenska aj po 29. septembri 1938. Naproti tomu ústavný dekrét prez. Republiky č. 11/1944 Úr. Věst. označuje všetky právne normy vydané na našom území /okrem možnosti výnimiek / za neplatné po podpísaní Mníchovskej dohody. 
občianske i vojenské. " ${ }^{34}$ Vyjadrením politických ciel'ov založených na tradičných socialistických požiadavkách zbavenia všetkého útlaku a triedneho vykoristovania všetkého l'udu bola v dokumente prijatá výzva na organizačné zlúčenie s l'avicovou čast'ou slovenskej sociálnej demokracie. ${ }^{35} \mathrm{~V}$ konečnom dôsledku to smerovalo k roztriešteniu Sociálnodemokratickej strany na Slovensku, a tým aj k celistvému politickému posilneniu l'avicového spektra zjednoteného hnutia odporu na Slovensku.

Slovenským komunistom sa tak počas Povstania podarilo získat' lavicovú čast' slovenských sociálnych demokratov, ku ktorému došlo na zjednocovacom zjazde 17. septembra 1944 v Banskej Bystrici. Vo svojej politickej i organizačnej podstate išlo jednoznačne o pohltenie slovenských sociálnych demokratov, ktoré sa navonok nezakryte prejavilo aj v prijatom spoločnom názve strany - Komunistická strana Slovenska.

Predstavy zlúčenej Komunistickej strany Slovenska o povojnovom usporiadaní obsahovala Rezolúcia zjednocovacieho zjazdu v mnohých smeroch prinášajúca prelomové pohl'ady na povojnový charakter režimu spoločnej štátnosti. Niektoré z nich mali zásadný vplyv a dosah na povojnové transformačné procesy.

V Rezolúcii zjednocovacieho zjazdu sa opätovala požiadavka samobytnosti slovenského národa, ako samostatného člena slovanskej rodiny, vyjadrujúca sa špecifikáciou povojnovej štátnosti aj v navonok označovanej podobe Česko - Slovensko pri zachovaní jej demokratického substrátu a vnútornej pevnosti. Táto mala vychádzat' zo zamedzenia uplatňovania nerovnosti národných subjektov v nej žijúcich v spojení ,, Pevne veríme, že $k$ takejto dohode príde, a že nikto nebude si uplatňovat’ predpráva, ktoré by nútili náš národ hl’adat' cesty k iným bratským národom "/ podč. P. M./. ${ }^{36}$ To všetko v unitárnom spoločnom štátnom útvare.

Hlavný dôraz sa však kládol na transformáciu celospoločenských pomerov. Z pozície marxistických ideí, východiskom $\mathrm{k}$ tomu sa stalo odmietanie pomerov v časoch predmníchovského československého štátu, poukazovaním na biedne postavenie všetkých vrstiev pracujúcich/robotníkov, rol’níkov a pracujúcej inteligencie/. ${ }^{37} \mathrm{~V}$ súvislosti s tým sa v Rezolúcii nastolila požiadavka na takú podobu vnútorného povojnového usporiadania, ktorá nanovo vyrieši otázky hospodárske a sociálne. Menovite,

34 Pozri bližšie: Vyhlásenie Komunistickej strany Slovenska, vytyčujúce základné ciele Slovenského národného povstania, PREČAN, V.: Slovenské národné povstanie, Dokumenty. Bratislava: Vydavatel'stvo politickej literatúry, 1965, s. 397.

35 „V našom boji postupovali sme spoločne s väčšinou sociálno-demokratických súdruhov, ktorí, ako my, viedli protifašistický boj. Tento spoločný boj vzájomným želaním vyústi v jednotu socialistického robotnickeho a rolníckeho hnutia na Slovensku a vjednotnú stranu pracujúceho l'udu. "In: Ibidem, s. 398.

36 Ibidem, s. 521. V danej vyjadrenej relácii je možné sa domnievat', že v opačnom prípade by sa črtala možnost' návratu predstáv slovenských komunistov k svojmu programu štátneho pripojenia územia Slovenska do rámca Sovietskeho zväzu z roku 1941. Označovanie povojnového štátu v podobe Česko - Slovensko bolo len návratom k pôvodnému termínu, ktorý sa vyskytoval v medzinárodných mierových zmluvách tzv. versaillského systému ako dôsledku poprvovojnového usporiadania európskych pomerov. V Rezolúcii zjednocovacieho zjazdu sa nenadväzovalo na vyhlásenie autonómneho postavenia Slovenskej krajiny z roku 1938.

37 „, Všetky zisky z robotníkovej práce inkasoval kapitalistický podnikatel’. Prevažnú väčšinu pôdy má v rukách vel'kostatkár. Inteligencia je platená odrobinkami zo stola podnikatel’a. “ Ibidem, s. 521. 
a v konkrétnostiach: ,, Požadovat' budeme socializáciu tovární a podnikov, bánk, odovzdanie pôdy malým rolníkom, primerané postavenie inteligencie, upravenie celého štátneho a spoločenského stroja podl'a našich socialistických ideálov. "38

Predurčovala sa tak nezlučitel'nost' prevahy rezolútnych socialistických, nie primerane sociálnych, zásahov do demokratického systému predmníchovského československého štátu. Oporou k tomu malo byt' politické zdôrazňovanie, vo svojej podstate však vágne, že nositel’om politickej moci v štáte bude pracujúci l'ud tvoriaci obrovskú väčšinu obyvatel'stva. Navyše v dokumente deklarovanom spojení, že ,, Jednotná socialistická strana, Komunistická strana Slovenska, je a bude zástupcom najširšich vrstiev robotnictva, rol'níctva a pracujúcej inteligencie, bude iniciátorkou a organizátorkou ...zápasu o lepšie usporiadanie osudu pracujúcich vrstiev. Opierat' sa budeme o mohutný Sovietsky zväz a jeho Červenú armádu... "39

Nemožno preto pochybovat', že v danom historickom okamihu uvádzané prepojenie slovenských komunistov ako jedinečného a proklamovaného jediného zástancu vôle a potrieb väčšiny obyvatel'stva $v$ povojnovom československom štáte vyjadrovalo svojvol'né prisvojenie si tejto pozície pro futuro. Spolu s vytýčením východiskových pozícií zásadných premien v črtajúcich sa politických zápasoch $\mathrm{s}$ ciel’om získania rozhodujúcej politickej moci v povojnovom československom štáte. Načrtnutý program sa mal realizovat' pod terminologickým pláštikom l'udovej demokracie, ako prvý krát použitý terminus technicus, symptomaticky následne používaný na označovanie podoby reálne existujúceho povojnového československého režimu po roku $1945,{ }^{40} \mathrm{~V}$ spojení s východiskovým programovým dokumentom slovenských komunistov, riadených celosvetovým bol'ševickým moskovským centrom i gottwaldovským vedením KSČ, je nemožné nepochybovat', že idea povojnového l'udovodemokratického zriadenia bola len stratégiou pre presadzovanie sledovaného ciel'a $\mathrm{v}$ podobe nastolenia rozhodujúcej komunistickej politickej moci v povojnovom československom štáte. $\mathrm{V}$ danom povstaleckom čase, i v čase nielen do porážky nacistického Nemecka, bolo takticky nevyhnutné vytvárat' a udržiavat' pláštik transformácie predmníchovských pomerov demokratickou cestou, nenásilnou cestou. ${ }^{41}$

Vel'avravným faktom bola skutočnost', že ani do roku 1945 ani v bezprostredne povojnových rokoch, nedošlo k exaktnému vymedzeniu znakov termínu l'udová demokracia. Znamenalo to, že jej obsah sa postupne modeloval v politickom zápase o charakter povojnovej štátnosti, nesporne ovplyvňovaný zásadným medzinárodným faktorom vel'mocenským postavením Sovietskeho zväzu v stredoeurópskom priestore - potvrdeným výsledkami jaltskej i postupimskej konferencie tzv. Vel'kej trojky.

Úsilie o transformačný proces povojnových pomerov sa prejavoval tiež v rámci tzv. Občianskeho bloku reprezentujúceho nekomunistický kompaktný celok hnutia odporu na Slovensku. Tento sa v polovici septembra 1944 vyformoval do Demokratického klubu predstavujúceho zárodok tvoriacej sa novej politickej strany na Slovensku.

38 Ibidem, s. 521-522.

39 Ibidem, s. 522.

40 „, Idea dôslednej l’udovej demokracie vyžaduje, aby pracujúci l’ud, ktorý tvorí obrovskú väčšinu obyvatel'stva, bol nositel'om politickej moci v štáte. "I Ibidem, s. 522.

41 Vnútroštátna stabilita Slovenskej národnej rady do značnej miery bola rozkolísaná vojenskou porážkou Slovenského národného povstania. 
Začiatkom októbra 1944 boli prijaté Programové zásady Demokratickej strany, ktorá pôvodne pozostávala $\mathrm{z}$ rôznorodo politicky orientovaných činitel'ov. Ich ciel'om bolo vytvorit' politickú stranu odrážajúcu realizmus potreby zmeny pomerov nielen na Slovensku v polohe protiváhy voči predstavám slovenských komunistov. Programové zásady Demokratickej strany rozhodne nereprezentovali politické zástoje zastávané politickými osobnostami v období predmníchovského Československa, ktoré tvorili jadro tohto nového politického smeru na Slovensku. Z hladiska štátoprávneho i táto politická strana $\mathrm{v}$ mnohých svojich predstavách a názoroch stála na pozíciách protibenešovskej koncepcie dôslednej štátoprávnej kontinuity, čo následne nepochybne ovplyvnilo podmienky koncipovania podoby povojnového usporiadania Československa.

Východiskovým atribútom Programových zásad sa tradične, tak ako vo všetkých povstaleckých dokumentoch, prezentovalo stanovisko existencie samobytného slovenského národa s precizovanými súvislost'ami. ${ }^{42}$ Všetky tieto, ako aj d’alšie, atribúty vyplývajúce z faktu podielu Slovenska na vlastnom oslobodení ozbrojeným Povstaním prejudikovali právo na to, aby na Slovensku celá štátna administratíva, súdy a štátne podniky boli v rukách domácich l'udí. Samozrejmou skutočnostou s tým spojenou bolo zachovanie jednoty povojnovej republiky pri garancii zabezpečenia aj primeraného podielu Slovenska na zákonodarnej, vládnej i výkonnej moci v štáte spolu s vyjadrenou predstavou, že ,... chceme mat' moderný, pokrokový, vnútorne usporiadaný a vyrovnaný, spravodlivý právny štát / podč. P. M. /.“43

V mnohých smeroch pozoruhodnými boli vnútropolitické predstavy obsiahnuté v Programových zásadách. Z nich predovšetkým odmietanie tak do druhej svetovej vojny v Československu uplatňovanej individualistickej ako aj komunistickou stranou presadzovanej sovietskej kolektivistickej hospodárskej sústavy. ${ }^{44}$ To však nič nemenilo na zásadnej skutočnosti uplatňovania princípu súkromného vlastníctva. K nemu samotnému demokrati zastávali triezve stanovisko s objektívnym hodnotením dvojakého navzájom protichodného jeho pôsobenia. ${ }^{45}$ Východiskovou premisou sa tak stala požiadavka demokratických inštitúcií aj na poli hospodárskeho podnikania. Pričom , Týmto snahám nevyhovuje ani liberalizmus, ani socializmus. Liberalizmus je prekonanou kon-

42 „Slovenčina bude na Slovensku úradnou rečou a vyučovacím jazykom na školách všetkých druhov a stupňov. Okrem toho nech je na územi celého štátu popri češtine štátnou rečou. Školy, kultúrne ustanovizne, osvetové zariadenia a podniky nech sú prostriedkami na pestovanie národného ducha, národnej výchovy a vzdelanosti. Spoločenské stavy a triedy nemôžu sa stavat' do protivy s funkciou národa a štátu. “, Programové zásady Demokratickej strany. PREČAN, V.: Slovenské národné povstanie, Dokumenty. Bratislava: Vydavatel'stvo politickej literatúry, 1965, s. 621.

43 Ibidem, s. 621.

44 „, Anijednazo známych hospodárskych sústav, či užideo individualistickú alebo o kolektivistickú, sama o sebe neposkytuje podklad pre vhodné riešenie hospodárskych a sociálnych otázok Slovenska. Preto neprikláñame sa jednoznačne ani k jednej z nich. "Ibidem, s. 623.

45 „, Súkromné vlastníctvo slúži na jednej strane zdravému pobádaniu k usilovnej práci, vzbudzuje záujem o tvorbu hodnôt a o slobodnú činnost’ vôbec, čím zabezpečuje jednotlivcovi i národnému kolektívu hospodársku a sociálnu nezávislost'. Na druhej strane jeho neobmedzená platnost' často zvádza $k$ vykoristovaniu spoločensky slabých a k bezohl'adnému hromadeniu bohatstva do malého počtu rúk. Aby sa tomu zabránilo, chceme mu uložit’ aj funkciu sociálnu. Preto musíme usmernit' jeho použivanie s náležitým ohl'adom na potreby celej národnej pospolitosti, a to i za cenu skrátenia práv jednotlivca. "Ibidem, s. 623-624. 
štrukciou. Socializmus vo svojej pôvodnej podobe, nakol'ko sleduje revolučné zmeny hospodárskej a sociálnej oblasti, je v niektorých ohl'adoch prakticky neuskutočnitel'ný. No tie požiadavky tohto systému, ktoré v našich pomeroch možno uskutočnit' bez naštrbenia záujmov národného kolektívu, si osvojujeme a chceme ich uviest' do života v takej miere, a akej to naše pomery dovolujú. " 46 Východiskom z predloženej antagonistickej negácie sa podla predstáv slovenských demokratov malo stat' družstevné podnikanie založené na princípe existencie súkromného vlastníctva.

Snaha Demokratickej strany v uvádzaných líniách nemala samoúčelný charakter. Bola tesne previazaná na transformačné predstavy v sociálnej oblasti ako najcitlivejšej sfére pre všetky rozvrstvenia obyvatel'stva. Východiskovým atribútom bolo úsilie o participáciu socialistického sociálneho videnia pri dôslednom zachovaní demokratického režimu povojnového československého štátu s posilnením prvkov centralizmu $\mathrm{v}$ jeho rozhodovacej činnosti. Nielen $\mathrm{v}$ procese spravodlivého rozdel'ovania všetkých hodnôt l'udskej práce prostredníctvom úpravy zaslúženej mzdy, obmedzovania hromadenia neprimeraných majetkov a dôchodkov. Tiež usmerňovaním výroby ,,... plánovitými zásahmi tak, aby vylúčil nezamestnanost', najmä robotníctva všetkých kategórii a duševných pracovníkov. Zásadne sme proti riešeniu nezamestnanosti podporami... Treba ju riešit' zamestnaním a prácou každého podl'a jeho sil a schopností. "“7 Vylučovalo sa aj riešenie nezamestnanosti emigráciou do cudziny.

Odborne nesporne prepracované transformačné úsilie Demokratickej strany nemožno hodnotit', v porovnaní s programovými ciel'mi slovenských komunistov, i komunistov ako celku, v zmysle boja o rozhodujúcu politickú moc v štáte. Programové zásady slovenských demokratov sa odvolávali na idey štátu tak ako ich sformuloval prvý prezident ČSR T. G. Masaryk pri vzniku československej štátnosti. ${ }^{48}$

Programové zásady Demokratickej strany z októbra 1944 predstavovali ucelený pohl'ad na bližšie, špecifikačné kontúry povojnového režimu l'udovodemokratického zriadenia $v$ celom československom štáte. Nesmierne triezve a vyvážené hodnotenie nemohlo $\mathrm{v}$ tejto podobe vyhovovat' zásadným, vo svojej podstate revolučno-triednym, predstavám komunistov $\mathrm{v}$ danom čase ,ale ako ukázal vývoj, aj neskôr. Vytváralo však predpoklady na demokratický, konštruktívny dialóg bez vyhrocovania vzájomných vzt’ahov $\mathrm{v}$ pomere $\mathrm{k}$ domácemu komunistickému spojencovi $\mathrm{v}$ rámci zjednoteného hnutia odporu. Bolo zároveň aj politickou platformou pre dosiahnutie úprimného, poctivého kompromisu vo vzt’ahu k predstavám jedinej štátnej reprezentácie Československa so sídlom v Londýne, bez ktorej nebolo možné riešit pomery v povojnovom obnovenom štáte. Jeho nezávislost' od bipolárnych politických konštrukcií predstavovalo tú povestnú Achillovu pätu v relácii črtajúceho sa vel’mocen-

46 Ibidem, s. 624.

47 Ibidem, s. 625.

48 „Prezident - Osloboditel’ zanechal odkaz, že národy sa udržujú tými ideami, z ktorých vznikli.

I vzkriesená ČSR musi dat' každému občanovi jasnú a samozrejmú štátnu myšlienku, ktorá jej dáva zmysel a vnútorný obsah. Štátnou ideou ČSR je, aby všetky štát udržujúce národy a všetci jej príslušníci a občania našli v nej ochrankyňu slobôd a práv, záruku pokroku, blahobytu a št’astného života... Tejto myšlienke má slúžit' podnikanie akéhokol'vek druhu každého a všetkých, menovite národná výchova, kultúra a osveta. Činnost', ktorá sa dostáva do rozporu s ideou štátu, je škodlivou a ako taká má sa zamedzit', i keby bola akokol’vek odôvodnená. “ Ibidem, s. 622. 
ského podelenia stredoeurópskeho priestoru. V podmienkach Československa pod kuratelou Sovietskeho zväzu.

$\mathrm{Na}$ koncepcii formovania predstáv l'udovodemokratického zriadenia $\mathrm{v}$ povojnovom československom štáte sa podiel'alo aj jediné odbojové zoskupenie reprezentujúce československú štátnost', uznané mocnost’ami protihitlerovskej koalície - londýnsky Benešom vedený odboj. ${ }^{49}$ Jeho pozícia mala však charakter obrany presadzovania dôslednej obnovy predmníchovských štátoprávnych pomerov vo všetkých oblastiach správy štátu a charakteru jeho režimu. Uznanie a potvrdenie obnovenia predmníchovských štátnych hraníc mocnost’ami trojkoalície, bez vyjadrenia názorových stanovísk na podobu vnútorného režimu štátu, umocňovalo u prezidenta Beneša snahu rozvíjat' svoje predstavy o dôslednej štátoprávnej kontinuite ako prirodzenom fakte bez chápania zmenených mocenských pomerov v stredoeurópskom priestore.

Benešova korelácia predstáv o akomsi moste povojnového Československa medzi východom a západom už v tom období zabudla akceptovat' historicky predurčujúcu skutočnost’ postavenia predvojnového predmníchovského Československa v polohe nárazníkového štátu / tzv. cordon sanitaire / voči prenikaniu bol'ševickej ideológie. Nesporná štátnická zrelost' realistického demokratického politika tak vo svojich povojnových absolútne scestných vizionárskych chimérach nemohla nenarazit' na nerelevantnost' totalitnej bol'ševickej ideológie reprezentovanej J. V. Stalinom. Absentovalo aj historické povedomie o neustále opakujúcich sa imperiálnych snahách ešte z čias cárskeho Ruska. To v konečnom dôsledku potvrdzoval neoblomný povojnový režimový status vývoja na československom území.

Dekretálna činnost’ prezidenta E. Beneša v londýnskom exile, vychádzajúca z povahy dôslednej štátoprávnej kontinuity, však výraznejšie ani nemohla reflektovat' názory na transformáciu predmníchovských pomerov. Právny status sa nachádzal v ústavnom dekréte prezidenta republiky č. 11/1944 Úr. Věst. O obnovení právneho poriadku prijatom 3. augusta 1944. Jeho známa základná idea spočívala v zásade, že československý právny poriadok v obnovenom povojnovom Československu bude pozostávat' z ústavných a obyčajných zákonov i iných právnych noriem platných na jeho území do 29. septembra 1938 vrátane. Vymedzené kritérium zároveň znamenalo, že všetky právne normy prijaté na tomto území po tomto termíne, t. j,. od 30. septembra 1938 nebudú jeho súčast'ou. ${ }^{50}$ Napriek tomu, vo všeobecnejšom zamyslení sa,

49 Konštituoval sa v roku 1940, medzinárodnoprávne uznanie dosiahol 21. júla $1940 \mathrm{~s}$ formálnym označovaním termínom Dočasné štátne zriadenie československé. Skladalo sa z troch dočasných, v zahraničí pôsobiacich najvyšších štátnych orgánov: a/ prezident republiky s pôsobnost'ou výkonu zákonodarných právomocí tak v rovine ústavných zákonov / ústavné dekréty prezidenta republiky/ako aj obyčajných zákonov/dekréty prezidenta republiky/, b/ vláda menovaná prezidentom, mala obligatórnu zákonodarnú iniciatívu vo vzt’ahu k zákonodarnej právomoci prezidenta, c/ štátna rada v postavení poradného orgánu vo vzt’ahu k prezidentovi.

50 Hlava I., prvý oddiel, Čl. 1 ústavného dekrétu doslovne znel:,, 1. Ústavné a iné právne predpisy československého štátu vydané do 29. septembra 1938 vrátane, pochádzajúce zo slobodnej vôle československého l'udu, a sú československým právnym poriadkom.2. Predpisy vydané $v$ oblasti tohto poriadku v dobe, kedy československý l'ud bol zbavený svojej slobody /doba neslobody/, nie sú súčastou československého právneho poriadku. Doba neslobody je doba od dn̆a 30. septembra 1938 až do ďna, ktorý bude určený vládnym nariadením. " Hlava I., prvý oddiel, Čl. 2 ústavného dekrétu doslovne znel:,,1. Z vôle československej zákonodarnej 
nemožno popriet' jeho nenahraditel'ný právny základ povojnového konštituovania sa československej štátnosti. ${ }^{51}$

V podstate jediným výrazným zásahom do transformačného procesu predmníchovských pomerov, pred ukončením vojnového konfliktu, bol ústavný dekrét prezidenta republiky č. 18/1944 Úr. Věst. O národných výboroch a dočasnom Národnom zhromaždení prijatý 4 . decembra $1944 .^{52}$

Predmetný Ústavný dekrét v rovine zakotvenia nového systému orgánov miestnej správy sa zrodil v ostrom strete dvoch politických koncepcií: 1./ komunistickej založenej na existencii a činnosti revolučných národných výborov na domácom území s prevahou vplyvu komunistických činitel'ov v nich. Fundamentalizovat' sa tým mali predpoklady pre sledované prevratové zmeny v zmysle dlhodobých ideových socialistických ciel'ov komunistického hnutia ako celku, 2./ nekomunistickej, reprezentovanej systémom Dočasného štátneho zriadenia československého. Teda dôsledná obnova systému orgánov predmníchovskej miestnej správy.

Obidve koncepcie vo svojej pôvodnej podobe predstavovali nepriechodný protiklad. Z pohl'adu ešte stále nezavíšeného druhovojnového konfliktu, východiskom bolo obojstranne prijatel'né zakotvenie dovtedy netradičnej formy miestnych správnych orgánov v podobe národných výborov. Spolu však s významným obsahovým zákonným zakotvením ich dočasnosti a príliš všeobecným rámcom ich faktických právomocí. Zákonodarca E. Beneš tým nedvojzmyselne vyjadril, že otázku vzájomného pomeru národných výborov a zavedeného systému miestnej správnej organizácie v období predmníchovského Československa bude potrebné v obnovenom povojnovom štáte len riešit'. Vychádzal z predpokladu opadnutia revolučnej vlny v povojnových rokoch.

V rovnakých dimenziách sa prejavoval aj český domáci odboj. Spoločnou jednotiacou platformou nekomunistického hnutia odporu bola povojnová obnova národnej slobody a štátnej suverenity spolu s prejavujúcim sa radikálnym nacionalizmom majúcim podobu transferu všetkých Nemcov z územia povojnového Československa. Jeho ideová platforma korešpondovala s dôsledným obnovením predmníchovského štátneho režimu s rezervovanými sociálnoreformnými i d'alšími otázkami, ktoré nepredstavovali výraznejšie transformačné zmeny v povojnovom štátnom režime. Tobôž nevytvárali čo i len obsedantnú potrebnost' vyjadrovat' sa k zásadným otázkam majúcim podobu nového l'udovodemokratického zriadenia. K zásadným zmenám nedošlo ani zjednotením jeho základných prúdov vytvorením orgánu pod názvom Ústredné vedenie odboja domáceho / ÚVOD/. ${ }^{53}$

moci možno na prechodnú dobu nad'alej použivat' predpisy uvedené v odseku 2 čl. 1 , ktoré sa nepriečia svojím obsahom zneniu alebo demokratickým zásadám československej ústavy / ústavnej listiny, jej súčastí a zákonov ju meniacich a doplňujúcich, vydaných do 29. septembra 1938/. Celkom sú však z použivania vylúčené predpisy z doby neslobody z odborov súdneho práva trestného, súdneho konania trestného, práva osobného a práva rodinného. “.

51 Na druhej strane aj snaha o vymedzenie sa Dočasného štátneho zriadenia československého ako jediného centra protinacistického odboja tak doma ako aj v zahraničí.

52 Rámec ústavného dekrétu bol vypracovaný Zahraničným byrom Komunistickej strany Československa v Moskve.

53 Vytvorený zjednocujúci orgán s politickou orientáciou na E. Beneša nepredstavoval monolitný názorový celok. Názorové spektrum sa prejavovalo v rovine od vážnych výhrad voči Sovietskemu zväzu až po rezervovaný postoj k západným vel’mociam. 
Na rozdiel od občianskeho odboja vedúcou ideou českého komunistického odboja bola najprv sociálna revolúcia nepriamo spájaná s revolúciou proletárskou. $\mathrm{V}$ etape po vypuknutí druhej svetovej vojny upriamenie sa na socialistickú revolúciu s následnou modifikáciou a zoslabením favorizovaných revolučných ciel'ov, po napadnutí Sovietskeho zväzu nacistickým Nemeckom, aj ked' komunistický odboj sa ich nikdy nevzdal. ${ }^{54}$ Vytvorili sa tak predpoklady pre možné i žiaduce zjednotenie komunistického i občianskeho hnutia odporu podporovaného aj londýnskym vedením československého odboja. Pokus o vytvorenie spoločného Ústredného národne revolučného výboru však stroskotal. ${ }^{55}$ Absencia spoločnej programovej platformy v konečnom dôsledku prispela $\mathrm{k}$ povojnovému posilneniu postavenia komunistov v československom štáte. Podiel'ala sa aj na vytvorení východiskového predpolia pre komunistický štátny prevrat v časovej dimenzii od jesenných mesiacov 1947 po februárové dni 1948.

Napriek nemalému úsiliu a nemnohým l'udským obetiam domáci českí nekomunistický i komunistický odboj nedokázali ani v predposlednom roku vojny, v roku 1944, zorganizovat' širšie masové vystúpenie obyvatel'stva proti nemeckej okupácii a jej domácim prisluhovačom. Nedošlo tak k sformulovaniu východiskových predstáv povojnových transformačných procesov tak ako tomu bolo na území Slovenska.

\section{Literatúra:}

- BENKO, J. et al.: Dokumenty slovenskej národnej identity a štátnosti, II. Bratislava: Národné literárne centrum, 1998.

- BERLANSKÝ, M.: Ideový obsah osláv 20. výročia povstania. In: Historický časopis, 2017, 65, 3, s. 515-539, Bratislava.

- JÁGER, R.: About correctness and justice of the representatives of the czechoslovakian public authority in 1938 - 1939. In: Socioekonomické a humanitni studie (vedecký časopis). 1/2012, volume 2, Praha, 2012, s. 26-30.

- JÁGER, R.: Dictatorship and discrimination, and its consequenes in law during war time Slovak republic. In: Právní a ekonomické problémy současnosti III. Ostrava: KEY Publishing. 2007, s. 5-15.

- MIČEV, S. et al.: Slovenské národné povstanie 1944. Banská Bystrica: Múzeum Slovenského národného povstania, 2010.

- LACKO, M.: Slovenské národné povstanie 1944. Bratislava: Slovart, 2008.

- PLEVZA, V.: Dejiny Slovenského národného povstania, 3. Zväzok. Bratislava: Pravda, 1984.

- PlevZA, V. et al.: Dejiny Slovenského národného povstania 1944 - 5. zväzok. Bratislava: Pravda, 1985.

- PREČAN, V: Slovenské národné povstanie, Dokumenty. Bratislava: Vydavatel'stvo politickej literatúry, 1965.

54 Východiskovým postulátom českého komunistického odboja, tak ako aj komunistického odboja na Slovensku, bolo v zmysle záverov VII. Kongresu Komunistickej internacionály upriamenie prioritnej pozornosti na vytvorenie platformy širokého protifašistického frontu.

55 Po vel'mi nepriaznivom stave českého domáceho odbojového hnutia v dôsledku heydrichiády / zjednotené občianske hnutie odporu ÚVOD bolo zlikvidované/jeho opätovný vzostup nastáva v roku 1943. Nová etapa je poznamenaná silnejúcim latentným zápasom medzi nekomunistickým a komunistickým odbojom o hegemóniu českého národa. 
- RÁKOŠ, E.: Slovenské národné orgány v dokumentoch. Bratislava: Pravda, 1977.

- SZABÓ, M.: "Clerical Fascism"? Catholicism and the Far-Right in Central European Context (1918-1945). In: Historický časopis, 2017, 65, 4, s. 675-687, Bratislava.

\section{Summary: Programmatic Starting Points for the Transformation of pre-Munich Statehood into a People's Democratic Regime}

Unlike the civic resistance, the leading idea of the Czech communist resistance was at first indirectly connected with the proletarian revolution. In the stage after the outbreak of World War II, it focused on the socialist revolution with the subsequent modification and weakening of favored revolutionary goals, after the invasion of the Soviet Union by Nazi Germany, although the communist resistance never gave them up. This created the preconditions for a possible and desirable unification of the communist and civic resistance movements, also supported by the London leadership of the Czechoslovak resistance. However, the attempt to create a joint Central National Revolutionary Committee failed. The absence of a common programming platform ultimately contributed to the post-war strengthening of the position of the Communists in the Czechoslovak state. She also participated in the creation of a starting point for a communist coup d'état in the time dimension from the autumn months of 1947 to February 1948. Despite considerable efforts and few human sacrifices, the Czech non-communist and communist resistance failed to organize population's opposition to the German occupation and its domestic minions. Thus, the initial ideas of post-war transformation processes were not formulated, as was the case in Slovakia.

prof. JUDr. Dr. h. c. Peter Mosný, CSc. Profesor emeritus, Harčárova 13, 040 18, Košice, Krásna, Slovenská republika 